\title{
Hoe bestuurskundig is de bestuurskunde?
}

\author{
Nederlandse bestuurskundigen vergeleken met hun Europese \\ vakgenoten $^{*}$
}

Stefanie Gadellaa, Dion Curry \& Steven Van de Walle

Dit is het eerste stuk van de serie artikelen over de staat en toekomst van de Bestuurskunde (zie ook de inleiding bij dit nummer). Sinds ruim veertig jaar is het mogelijk bestuurskunde als opleiding te volgen. Het bestuurskundig onderzoek kent een veel langere geschiedenis, waarin Van Poelje een belangrijke pioniersrol heeft vervuld. De artikelen in deze serie reflecteren op de bestuurskunde van dit moment en schetsen mogelijke ontwikkelingen. Bovendien poneren zij een reeks prangende stellingen en vragen voor bestuurskundige onderzoekers en practitioners over hun eigen vakgebied en wellicht over henzelf.

Zolang de bestuurskunde bestaat, is er discussie over de vraag of de bestuurskunde zich meer op de praktijk of juist op de pure wetenschap moet focussen. Door de tijd heen zijn de meningen van bestuurskundigen hierover verdeeld. Hiernaast is het de vraag of de bestuurskunde een eigen discipline is, dan wel een onderdeel van de politicologie, het recht of de managementwetenschap. Dit artikel toont hoe bestuurskundigen zelf de discipline en de ontwikkelingen erin zien, op basis van een survey onder Europese bestuurskundigen. De Nederlandse bestuurskundigen worden hierbij vergeleken met Europese bestuurskundigen. Tussen Nederland en Europa bestaan grote verschillen in de discipline. Ten eerste is de bestuurskunde als afzonderlijke discipline in Nederland belangrijker dan in de overige Europese landen, waar de politieke wetenschappen een belangrijke rol spelen. Wat betreft de spanning binnen de bestuurskunde, ontwikkelt de bestuurskunde zich in Nederland minder richting de praktijk dan de bestuurskunde in andere landen.

\section{Inleiding}

Wat betekent het voor de bestuurskunde om bestuurskundig te zijn? Om deze vraag te beantwoorden moeten we ingaan op de relatie tussen de bestuurskunde als wetenschap en de bestuurspraktijk, en reflecteren op de positie als een discipline binnen een groter geheel van moeder- of zusterdisciplines zoals de politicologie, recht, of management. De discipline bestuurskunde vervult twee belangrijke rollen. Ten eerste is bestuurskunde een academische discipline met een wetenschappelijke benadering. Daarnaast heeft de bestuurskunde een belangrijke

* Het onderzoek dat tot deze resultaten heeft geleid, is deels gefinancierd door het Zevende Kaderprogramma van de Europese Unie, onder overeenkomst nr. 266887 (Project COCOPS), Socio-economic Sciences and Humanities. 
relatie met de praktijk van het openbaar bestuur. Bestuurskundigen moeten niet alleen wetenschappelijk onderzoek uitvoeren; dit onderzoek moet ook worden vertaald naar de praktijk. Deze verschillende taken zorgen voor spanningen binnen de discipline. Een belangrijke kwestie is immers wie de bestuurskundigen in eerste instantie moeten dienen: de wetenschap of de praktijk.

De bestuurskunde is in Nederland geleidelijk geëvolueerd van een interdisciplinaire wetenschap met het publieke domein als focus naar een wetenschap met (quasi-)disciplinaire status. Dit betekent dat de Nederlandse bestuurskunde in tegenstelling tot die in veel andere landen een zekere onafhankelijkheid heeft verworven van disciplines als sociologie, recht, politieke wetenschappen en management. Tegelijk leunt ze theoretisch, conceptueel en methodologisch sterk op deze disciplines.

Aangezien de bestuurskundigen samen de discipline bestuurskunde vormen, kunnen zij ons inzicht geven in de status en de ontwikkeling van de discipline. In dit artikel worden op basis van een in 2013 uitgevoerde survey de opvattingen van Nederlandse academische bestuurskundigen vergeleken met die van vakgenoten in de rest van Europa. Randma-Liiv en Connaughton (2005) geven aan dat er grote verschillen bestaan tussen de verschillende Europese landen. Nederland verschilt van andere Europese landen omdat hier ten eerste, vergeleken met andere landen, een lange traditie van de bestuurskunde bestaat (Kickert \& Stillman, 1999). Bovendien heeft de Nederlandse bestuurskunde, in tegenstelling tot die in andere Europese landen, een eigen geschiedenis (Korsten, 2006). Het is daarom interessant te zien hoe Nederland zich in de bestuurskunde onderscheidt van de andere Europese landen op de twee hierboven besproken dimensies.

In het vervolg van het artikel wordt eerst een overzicht gegeven van de bestaande literatuur met betrekking tot de spanning tussen wetenschap en praktijk, en de disciplinaire status van de bestuurskunde. Vervolgens worden de gebruikte data besproken en wordt een korte beschrijvende analyse gegeven van het demografisch profiel van de respondenten. Hierop volgt een analyse van de verschillen in de discipline van de bestuurskunde tussen Nederland en de rest van Europa. Tot slot worden de verschillen tussen Nederland en de rest van Europa met betrekking tot de spanning tussen bestuurskunde als wetenschap en de praktische rol van de bestuurskunde, en de verschillen met betrekking tot de disciplinaire status in de conclusie kort samengevat. Tevens wordt in de conclusie ingegaan op de betekenis van deze verschillen.

\section{De spanning wetenschap versus praktijk en de disciplinaire status van de bestuurskunde}

\section{Spanning wetenschap versus praktijk}

Zoals reeds besproken bestaat er een duidelijke spanning binnen de bestuurskunde tussen wetenschap en praktijk. De verhouding tussen wetenschap en praktijk is in de geschiedenis van de bestuurskunde altijd een belangrijk onderwerp geweest. Van Poelje (1942), de grondlegger van de Nederlandse bestuurskunde, was in zijn tijd van mening dat de bestuurskunde een toegepaste wetenschap is. 
Dit betekent dat de toepasbaarheid in de praktijk belangrijk is voor de bestuurskunde. Internationaal vinden we deze mening in de jaren zestig van de vorige eeuw ook onder meer bij Waldo (1968). Ook hij was, samen met een groep jonge onderzoekers, van mening dat de bestuurskunde een toegepast veld is. Momenteel wordt in Nederland veelal erkend dat de bestuurskunde een adviserende wetenschap moet zijn (Ringeling, 2007; Frissen \& Van Twist, 2010). Tegelijk wordt echter ook de behoefte tot verdere academisering erkend.

Op de bestuurskunde als toegepaste wetenschap bestond echter veel kritiek. De vraag ontstond of de bestuurskunde een onderdeel van de macht wil zijn. Volgens sommige bestuurskundigen past het de bestuurskunde wellicht beter om een onafhankelijke positie in te nemen (zie o.m. Frissen \& Van Twist, 2010). Daarnaast kende de bestuurskunde door het toegepaste karakter nauwelijks theorieën (Bushouse et al., 2011).

Mede door de bovengenoemde kritiek heeft de bestuurskunde zich de afgelopen jaren sterk gedistantieerd van de bestuurlijke praktijk. Academici richten zich meer op het publiceren in internationale tijdschriften (Posner, 2009). In Nederland is deze trend goed zichtbaar. Een onderzoek in 2010 toonde aan dat slechts $20 \%$ van alle publicaties van leden van het Netherlands Institute of Governance zijn gepubliceerd in het Nederlands (Van Bueren, 2010). Internationale tijdschriften worden echter slechts in zeer beperkte mate gelezen door mensen uit de praktijk (Bushouse et al., 2011). Hierdoor hebben de onderzoeken van bestuurskundige academici soms weinig waarde voor de praktijk, terwijl de onderwerpen waar bestuurskundigen onderzoek naar doen wel goed aansluiten bij de wensen van de praktijk (Gibsen \& Deadrick, 2010). Recenter onderzoek van Groeneveld, Bouwman en Van de Walle (2014) toont echter aan dat er slechts een beperkte tradeoff is tussen publiceren in het Engels en in het Nederlands. Concluderend wordt enerzijds gesteld dat de bestuurskunde een toegepaste wetenschap moet zijn en anderzijds dat zij zich moet distantiëren van de praktijk. Er is echter geen helderheid over de ontwikkeling die de bestuurskunde doormaakt met betrekking tot de spanning tussen wetenschap en praktijk. Onze studie gaat juist in op deze vraag, door het aan de bestuurskundigen zelf te vragen.

\section{Disciplinaire status van de bestuurskunde}

In West-Europa is de bestuurskunde pas echt opgekomen na de Tweede Wereldoorlog. Daarmee is het een relatief nieuwe discipline (Kickert \& Stillman, 1999). In de Oost-Europese landen heeft de bestuurskunde zich later ontwikkeld en is bestuurskunde nog erg nieuw. Er bestaan tussen landen grote verschillen in het standpunt met betrekking tot de vraag of theorie dan wel praktijk meer aandacht krijgt binnen de bestuurskunde (Rutgers, 2001). Er zijn echter ook landen waarin bestuurskunde geen zelfstandige studie is. De bestudering van het openbaar bestuur valt in deze landen onder andere disciplines, of vindt weinig tot niet binnen de universiteiten plaats. Doordat de bestuurskunde op verschillende manieren is ontstaan en verschillend is ontwikkeld, kan er niet worden gesproken van één Europese bestuurskunde (Randma-Liiv \& Connaughton, 2005).

Over de focus van de bestuurskunde bestaat geen overeenstemming. De bestuurskunde maakt van oudsher gebruik van kennis uit verschillende disciplines (Hon- 
deghem, 2013). De belangrijkste disciplines waaruit de bestuurskunde inzichten leent, zijn de rechtswetenschap, economische wetenschap, sociologie, politicologie, politieke filosofie, psychologie en communicatiewetenschap. De kracht van de bestuurskunde zou volgens Bovens, 't Hart en Van Twist (2007, p. 60) moeten zijn dat verschillende inzichten op zo'n manier worden geïntegreerd, dat het totaal beter is dan de som der delen. Op dit punt is de bestuurskunde echter nog niet aanbeland (Bovens et al., 2007, p. 60).

De focus van de bestuurskunde is de laatste jaren veranderd. Daar waar de bestuurskunde in veel landen nog steeds een sterk juridische insteek heeft, zien we dat deze juridische benadering aan belang heeft ingeboet (Moe \& Gilmour, 1995). Een andere trend is dat de bestuurskunde zich disciplinair deels heeft verplaatst van de politicologie en de rechtswetenschap naar de managementwetenschap (Moe \& Gilmour, 1995; Raadschelders, 2003, p. 375). Dit is bijvoorbeeld goed zichtbaar in het Verenigd Koninkrijk, waar in de jaren negentig business schools belangrijke thuishavens werden voor bestuurskundigen, of in de opkomst van de benaming 'public management' naast 'public administration' in dezelfde periode (Hughes, 1998; maar zie ook de relativering van Pollitt, 2003). Deze verschuiving kwam ook met een verandering in focus naar het intra-organisationele en het a-politieke (Talbot, 2005).

Volgens Zalmanovitch (2014) is de bestuurskunde gebaseerd op drie pijlers: politiek, recht en management. Door de tijd heen wisselt het belang van de verschillende pijlers. Deze conclusie sluit aan bij Hondeghem (2013), die eerder stelde dat het gebruik van verschillende disciplines afhankelijk is van het onderwerp. Tegelijk vindt Wright (2011) dat wanneer wordt gekeken naar de verwijzingen van en naar bestuurskundige tijdschriften dat er nauwelijks verwijzingen plaatsvinden naar onderzoek van andere disciplines. Rhodes (1991) geeft bovendien aan dat in de theorievorming slechts beperkt gebruikgemaakt wordt van andere disciplines. In bovenstaande beschrijving van de literatuur is gebleken dat ook met betrekking tot de disciplinaire status van de bestuurskunde de meningen verdeeld zijn. Bovendien is de focus van de bestuurskunde aan verandering onderhevig. In dit artikel schetsen we hoe bestuurskundigen dit zelf zien, en gaan we in op verschillen tussen landen.

\section{Data}

In het voorjaar van 2013 stuurden wij als onderdeel van het Europese COCOPSproject over de toekomst van de publieke sector een elektronische vragenlijst naar bestuurskundigen in Europa ${ }^{1}$ werkzaam aan universiteiten, die in de daar voorafgaande drie jaar hebben deelgenomen aan een selectie van internationale bestuurskundige academische conferenties (EGPA, IRSPM, IPSA-SOG, PMRA, NISPAcee). De enquête is gehouden onder senior-level academici (universitair docent of equivalent en hoger). Uiteindelijk heeft de enquête 299 bruikbare res- 
ponses opgeleverd, of een respons van 38,8\% (zie Curry, 2014 voor een gedetailleerde beschrijving van de onderzoekspopulatie en het veldwerk, op www.cocops. eu/work-packages/wp8-future-study). De grootste groep respondenten in de enquête is werkzaam in Nederland (57, ofwel 19,3\%), hetgeen niet verwonderlijk is gezien de omvang van het vakgebied in Nederland. Het land wordt bepaald aan de hand van de instelling waarmee men het meest recent stond geregistreerd op de deelnemerslijst van de conferentie.

Om de representativiteit van de enquête in Nederland te controleren zijn de gegevens van de respondenten vergeleken met de gegevens van de senior members van het Netherlands Institute of Governance. Hieruit blijkt dat de verdeling man/ vrouw vrijwel gelijk is. Wanneer wordt gekeken naar het jaar waarin de respondenten hun eerste $\mathrm{PhD}$ hebben behaald, blijkt echter dat de 'jonge' academici (PhD na 2000) oververtegenwoordigd zijn in de Nederlandse dataset. Deze oververtegenwoordiging van jonge academici kan de bevindingen uit de analyse beïnvloeden. Overigens kan dit probleem ook spelen bij de respondenten uit andere landen, aangezien de deelnamegraad aan internationale academische conferenties wellicht niet voor elke wetenschapper gelijk is. Alle respondenten van de enquête zijn aangesloten bij een hogeronderwijsinstelling en van de respondenten heeft $94 \%$ een $\mathrm{PhD}$ of equivalent. Een verschil tussen de Nederlandse respondenten (dit zijn dus de respondenten werkzaam aan een Nederlandse instelling) en die in de rest van Europa is terug te zien in de functieomschrijving van de respondenten. De meest genoemde functie in Nederland is universitair docent (NL: 38,6\%, EU: 20,7\%). In de rest van Europa is (full) professor de meest genoemde functieomschrijving (EU: 39,3\%, NL: 29,8\%). We maken geen onderscheid tussen voltijdse wetenschappers en zij die hun aanstelling combineren met een functie buiten de universiteit.

De respondenten is gevraagd na te denken over de toestand van de discipline en de algemene trends binnen het vakgebied. Aan de hand van de opvattingen van de academici vergelijken we wat de verschillen zijn tussen de Nederlandse academici en de academici in de overige Europese landen. Significantie werd statistisch getoetst met behulp van een t-toets.

\section{Disciplinaire achtergrond en oriëntatie}

Bestuurskunde wordt vaak gezien als een multidisciplinaire discipline die veel inzichten leent uit andere disciplines. In de enquête zijn meerdere vragen gesteld, waaruit het multidisciplinaire karakter van de bestuurskunde naar voren komt. Ten eerste is de respondenten gevraagd in welke discipline zij hun hoogste graad hebben behaald. Er zijn grote verschillen tussen Nederland en de rest van Europa. In Nederland is dit bij de meerderheid van de respondenten een graad in de bestuurskunde (52,2\%). In de rest van Europa heeft slechts een vijfde van de respondenten zijn hoogste graad behaald in de bestuurskunde. Buiten Nederland spelen de politieke wetenschappen de belangrijkste rol (34,5\%).

Bestuurskunde is een relatief jonge discipline (Kickert \& Stillman, 1999). Het ligt daarom voor de hand dat jongere academici vaker hun hoogste graad in de 
bestuurskunde hebben behaald dan oudere academici. Dit kan tevens een verklaring zijn voor het hoge percentage in Nederland. Wanneer de discipline waarin de hoogste graad is behaald wordt afgezet tegen leeftijd, blijkt dat er inderdaad relatief meer jonge academici zijn die hun graad in de bestuurskunde hebben behaald (29\% versus 20\%). Dit verschil is echter veel kleiner dan het verschil tussen Nederland en de rest van Europa. In figuur 1 worden de beschreven verschillen weergegeven. Van iedere discipline wordt aangegeven welk percentage van de respondenten in deze discipline zijn of haar hoogste graad heeft behaald. Hierbij dient te worden opgemerkt dat de vragenlijst respondenten vroeg zelf de discipline aan te duiden, en niet de officiële titulatuur van het diploma weer te geven.

Figuur 1 Discipline hoogste graad $(N=252)$

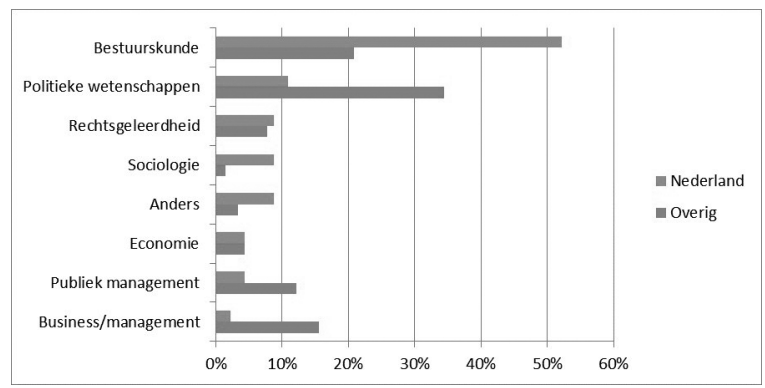

Deze verschillen in disciplinaire benadering zijn ook zichtbaar in de moederdisciplines die respondenten als belangrijk aanstippen binnen hun huidige onderzoek. Figuur 2 toont het gepercipieerde gemiddelde belang (op een schaal van 1 tot 7 ) van de moederdisciplines.

Figuur 2 Belang disciplines voor onderzoek $(N=269)$; schaal van 1 - not at all important, tot 7 - extremely important

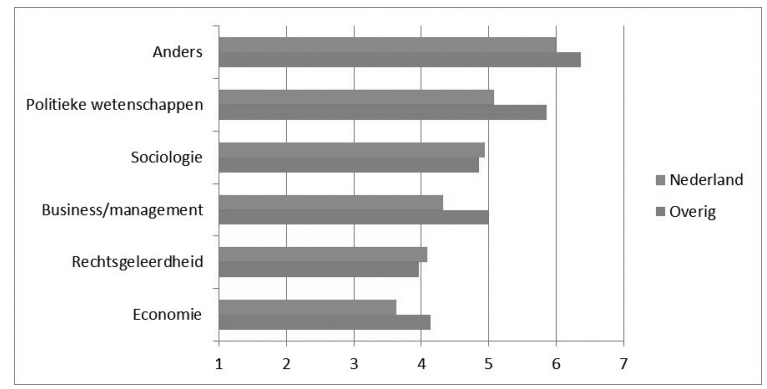

Er zijn twee significante verschillen tussen Nederland en de rest van Europa. Ten eerste zijn de politieke wetenschappen buiten Nederland significant belangrijker dan binnen Nederland ( $p=0,010$ ). Dit verschil sluit aan bij de verschillen in figuur 1. Een tweede verschil is dat in de rest van Europa business/management belangrijker is voor bestuurskundig onderzoek dan in Nederland ( $p=0,017)$. Ook dit verschil is duidelijk terug te zien in figuur 1 . In de literatuur wordt veelal aan- 
geduid dat management een steeds grotere rol krijgt binnen de bestuurskunde (Moe \& Gilmour, 1995; Raadschelders, 2003, p. 375). In Nederland blijkt dit minder het geval. Zowel binnen als buiten Nederland is de belangrijkste categorie 'anders'. Bij beide groepen is de meest genoemde andere discipline psychologie. Buiten Nederland wordt accounting meerdere malen aangehaald; binnen Nederland geen enkele keer. Zowel binnen als buiten Nederland zijn verschillende takken van de organisatiewetenschappen aangehaald.

Bovenstaande vraag richt zich op het onderzoek van de individuele respondenten. Er is ook gevraagd op welke discipline het departement waarbinnen zij werkzaam zijn, zich voornamelijk focust. De belangrijkste verschillen zijn wederom te zien bij bestuurskunde, politieke wetenschappen en business/management. In Nederland ligt bij een ruime meerderheid de focus van het departement op bestuurskunde (57,4\%). In de rest van Europa is dit percentage slechts $16.4 \%$. Dit bevestigt het unieke autonome positie van de discipline in Nederland. Buiten Nederland heeft de grootste groep aangegeven dat de focus ligt op de politieke wetenschappen (29,6\%). In Nederland is dit slechts $1,9 \%$. In figuur 3 is weergegeven welk percentage van de respondenten een discipline heeft aangevinkt.

Figuur 3 Hoofdzakelijke focus departement $(N=280)$

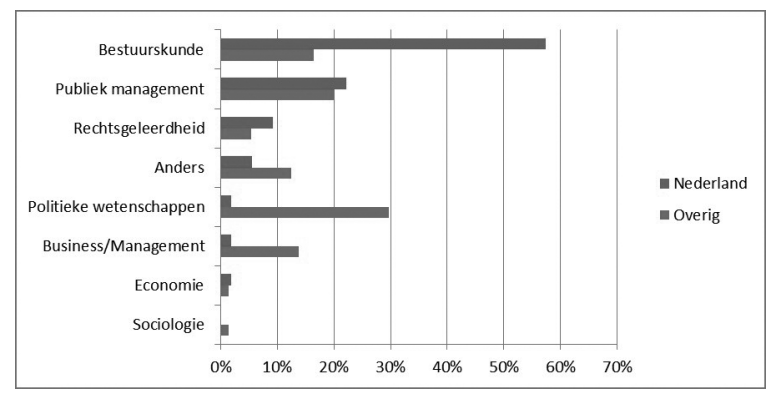

\section{Verschillen in tijdsbesteding en financiering}

In deze paragraaf wordt gekeken of er verschillen bestaan met betrekking tot de manier waarop er in departementen wordt gewerkt. Hierbij wordt gekeken naar de wijze waarop de bestuurskundigen aan universiteiten hun tijd verdelen over verschillende taken en naar de belangrijkste bronnen van financiering van onderzoek. Deze twee zaken geven een aanduiding van de verhouding tussen wetenschap en praktijk.

\section{Tijdsbesteding}

De respondenten is gevraagd aan te geven welk percentage van hun tijd zij besteden aan een aantal taken. Met behulp van deze vraag kan een beeld worden gevormd over de wijze waarop de academici hun tijd verdelen tussen onderwijs, onderzoek en andere taken en of deze verdeling anders is in Nederland dan in de rest van Europa. De grens tussen deze taken is niet altijd even duidelijk. Opnieuw 
is wat de respondenten zelf percipiëren als onderzoek, advisering, enzovoort, richtinggevend in de analyse.

\section{Figuur $4 \quad$ Percentage tijdsbesteding ( $N$ is tussen 41 en 280)}

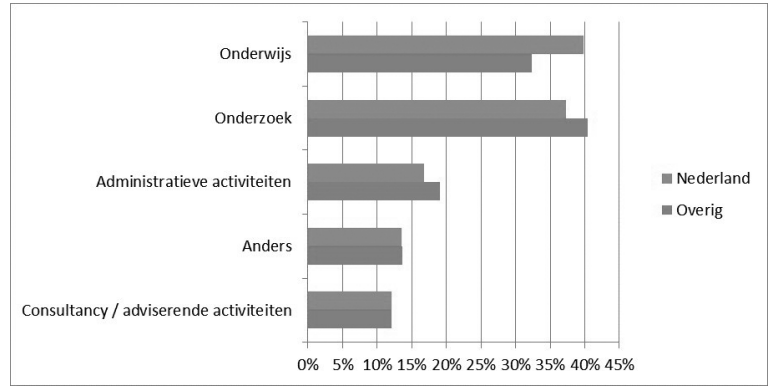

Opvallend is dat in Nederland de meeste tijd wordt besteed aan onderwijs en in de rest van Europa de meeste tijd aan onderzoek. Voor wat onderwijs betreft, is dit verschil significant $(\mathrm{p}=0,001)$ tussen Nederland en de overige Europese landen. Nederlandse bestuurskundigen besteden gemiddeld 39,81\% van hun tijd aan onderwijs. Het gemiddelde in de overige Europese landen is 32,29\%. In de inleiding is besproken dat bestuurskundig onderzoek ook waardevol kan zijn voor de praktijk. Uit figuur 4 blijkt echter dat zowel in Nederland als in de rest van Europa slechts een klein percentage van de tijd aan adviserende activiteiten wordt besteed, zeker in vergelijking met andere niet-primaire activiteiten, zoals administratieve activiteiten.

\section{Financiering}

In de enquête is ook gevraagd op een schaal van 1 tot 7 aan te geven hoe belangrijk verschillende bronnen van financiering zijn voor het onderzoek van de respondenten. De bron van financiering is van belang omdat dit een indicator is van de focus die de academici hebben. Wanneer de academici voornamelijk door de wetenschap worden gefinancierd, zal de wetenschap een belangrijke focus voor hen zijn.

In Nederland is de eigen universiteit de belangrijkste bron van financiering. In de rest van Europa is de financiering afkomstig van de nationale onderzoeksraden het belangrijkst. Hier is meteen een duidelijk significant verschil te zien tussen Nederland en de rest van Europa $(p=0,018)$. In Nederland wordt de financiering afkomstig van de Nederlandse Organisatie voor Wetenschappelijk Onderzoek (NWO) als minder belangrijk gepercipieerd dan de financiering door vergelijkbare organisaties in de rest van Europa.

Een tweede significant verschil tussen Nederland en de rest van Europa met betrekking tot financiering is het belang van training van ambtenaren en leidinggevenden $(p=0,033)$. De Nederlandse bestuurskundigen hechten meer belang aan deze vorm van financiering. Training van ambtenaren en leidinggevenden is een goede manier om theorie en praktijk te combineren. Bovendien kan hiermee 
de praktische relevantie van theorieën worden getest (Bushouse et al., 2011). In figuur 5 worden de uitkomsten weergegeven.

\section{Figuur 5 Financieringsbronnen onderzoek $(N=264-270)$}

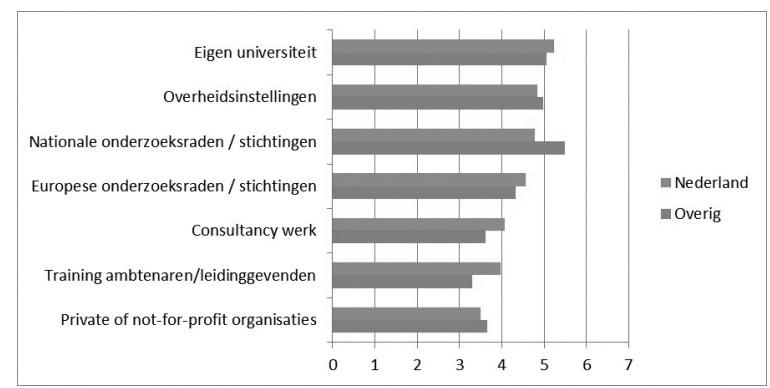

\section{Ontwikkeling bestuurskunde}

In de voorafgaande paragrafen is een beeld geschetst van de huidige situatie binnen de bestuurskunde. Het is echter ook interessant om te kijken naar de ontwikkeling binnen de bestuurskunde. In de enquête is aan de respondenten gevraagd om aan te geven op een schaal van 0 tot 10 welke ontwikkeling de bestuurskunde als een discipline doormaakt en welke ontwikkeling de discipline door zou moeten maken. Deze vragen laten duidelijk zien wat de verschillen zijn tussen Nederland en de rest van Europa met betrekking tot de eerder beschreven spanning in de discipline.

Ten eerste wordt de huidige ontwikkeling die de bestuurskunde volgens de academici doormaakt besproken. Bij twee categorieën is een duidelijk verschil te zien tussen Nederland en de rest van Europa. Ten eerste oriënteert de bestuurskunde zich in Nederland minder sterk op toegepast onderzoek dan in de rest van Europa $(\mathrm{p}=0,000)$. In Nederland geven de bestuurskundigen gemiddeld een score van 5,11, in de rest van Europa 6,27. Het tweede significante verschil tussen Nederland en de rest van Europa hangt samen met de oriëntatie op toegepast onderzoek, namelijk de praktijkoriëntatie $(\mathrm{p}=0,034)$. In Nederland doet deze ontwikkeling zich minder sterk voor dan in de rest van Europa (NL: 4,98, EU: 5,78). Deze twee verschillen tonen beide aan dat in Nederland de praktijk een minder grote rol speelt dan in de rest van Europa. Het is echter niet het geval dat de theorie zich in Nederland meer ontwikkelt dan in de rest van Europa. Volgens de respondenten in Nederland ontwikkelt de theorie met een gemiddelde score van 5,17 zich nauwelijks sterker dan de praktijk. In figuur 1 en 2 was reeds te zien dat de bestuurskunde als discipline in Nederland een belangrijkere rol speelt in Nederland dan in de rest van Europa. De rest van Europa maakt meer gebruik van andere disciplines. Dit wordt bevestigd door de gepercipieerde ontwikkeling van de bestuurskunde. In de rest van Europa wordt een sterkere ontwikkeling naar een interdisciplinaire bestuurskunde ervaren dan in Nederland. De beschreven verschillen worden verduidelijkt in figuur 6 . 
Figuur 6 Bestuurskunde wordt meer ... $(N=280)$

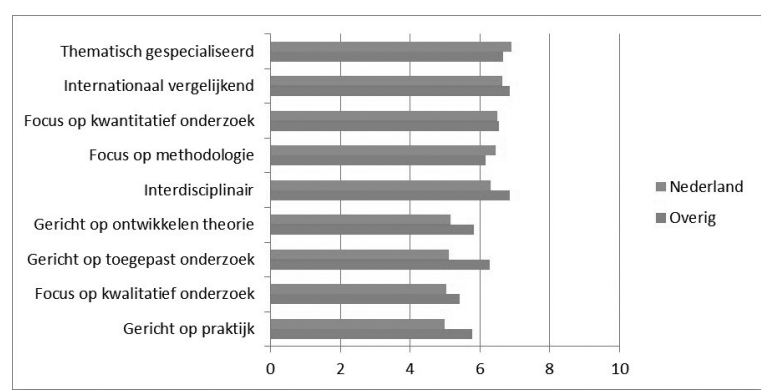

De gepercipieerde trend kan worden vergeleken met de gewenste trend. Ook hier is een aantal significante verschillen waar te nemen tussen Nederland en de rest van Europa. In Nederland vindt men in mindere mate dan in de rest van Europa dat de discipline meer interdisciplinair en internationaal vergelijkend moet worden $(p=0,013 ; p=0,000)$. Deze twee trends zijn in Nederland echter wel de meest gewenste trends. Nederlandse academici wensen dus een trend richting interdisciplinariteit en internationaal vergelijkend onderzoek, maar in minder sterke mate dan de Europese academici. Wellicht is de trend richting interdisciplinariteit in Nederland minder gewenst, omdat de bestuurskunde in Nederland meer een eigen discipline is dan in de rest van Europa. In de gewenste ontwikkeling van de bestuurskunde wordt geen significant verschil waargenomen dat betrekking heeft op de spanning binnen de bestuurskunde. In figuur 7 staan de gewenste ontwikkelingen van de bestuurskunde weergegeven.

Figuur 7 Bestuurskunde zou meer moeten worden ... $(N=280)$

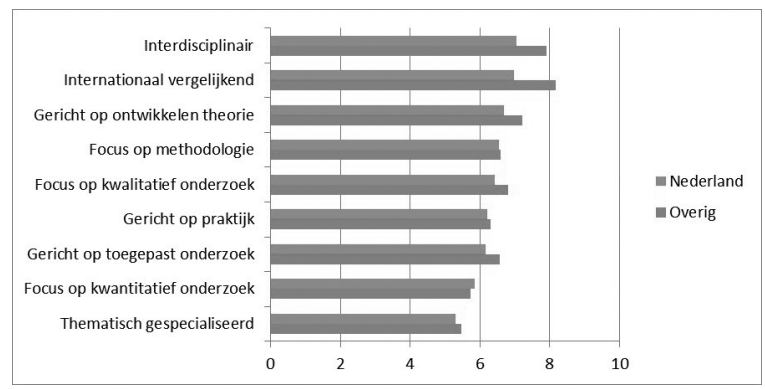

In figuur 8 worden de gepercipieerde en gewenste ontwikkelingen in Nederland met elkaar vergeleken. In figuur 6 is gebleken dat de Nederlandse academici minder een trend ervaren richting praktijkoriëntatie en toegepast onderzoek dan Europese bestuurskundigen. Opvallend is dat ook de gewenste trends met betrekking tot praktijkoriëntatie en toegepast onderzoek in Nederland minder sterk zijn dan in de rest van Europa. De gewenste trends zijn echter wel sterker dan de ervaren trends. Er zijn twee aspecten waarvan men vindt dat ze zich niet te ver door moeten zetten: de thematische specialisatie en de focus op kwantitatief onderzoek. 


\section{Figuur $8 \quad$ Vergelijking werkelijke en gewenste ontwikkeling van bestuurskunde} in Nederland $(N=54)$

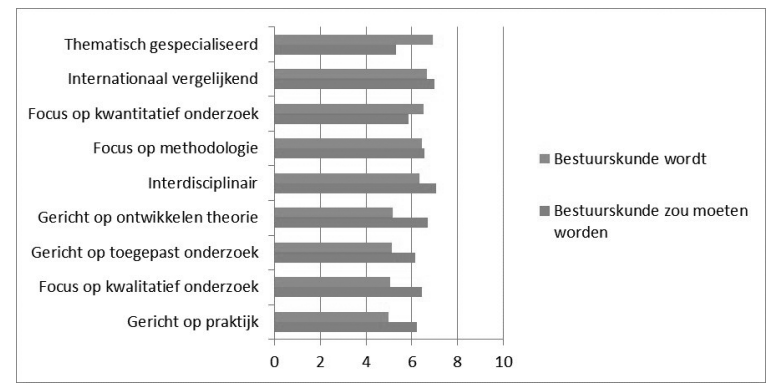

\section{Discussie en conclusie}

In dit artikel vergeleken we hoe in Nederland werkende bestuurskundigen de discipline zien in vergelijking tot hun collega's in andere Europese landen. Het duidelijkste verschil tussen Nederland en de rest van Europa heeft betrekking op de status van de discipline. In Nederland is de bestuurskunde als discipline belangrijker dan in de overige landen. In Nederland hebben meer ondervraagde academici een bestuurskundige achtergrond en meer departementen zijn gefocust op de bestuurskunde. In de overige Europese landen zijn de academici vaker afkomstig uit andere disciplines. Vooral de politicologie en managementwetenschap zijn in Nederland minder aanwezig. Daarnaast duiden Europese academici minder vaak dan Nederlandse academici de bestuurskunde aan als belangrijkste discipline voor hun onderzoek. Deze resultaten duiden erop dat in Nederland de bestuurskunde eerder kan worden gedefinieerd als een zelfstandige discipline dan in de rest van Europa.

De verschillen tussen Nederland en de rest van Europa met betrekking tot de spanning in de discipline zijn minder duidelijk dan de verschillen in de status van de discipline. In figuur 6 en 7 is gebleken dat de Nederlandse bestuurskundigen een minder sterke ontwikkeling ervaren en wensen richting praktijkoriëntatie en toegepast onderzoek dan de bestuurskundigen uit de rest van Europa. Dit duidt erop dat de Nederlandse bestuurskundigen minder belang hechten aan de praktijk dan de bestuurskundigen in de rest van Europa. Met deze figuren wordt echter de ontwikkeling aangegeven en niet de huidige situatie. Deze gegevens kunnen er dus ook op duiden dat de huidige bestuurskunde reeds meer praktijkgericht is in Nederland dan in de rest van Europa en dat er daardoor minder ontwikkelingen plaatsvinden richting meer toegepast onderzoek.

Ook de vragen met betrekking tot financiering en tijdsbesteding laten verschillen zien tussen Nederland en de rest van Europa. In Nederland besteden de ondervraagde academici meer tijd aan onderwijs dan in de overige landen. Dit verschil zou kunnen betekenen dat in Nederland, in vergelijking met de rest van Europa, de bestuurskunde meer wordt gezien als een klassieke discipline dan als een praktijkgerichte discipline, gegeven natuurlijk dat het hier zou gaan om bachelor- en 
masteronderwijs voor jonge studenten. Het belang van verschillende bronnen van financiering laat echter iets anders zien. In Nederland lijkt meer financiering afkomstig van trainingen van ambtenaren en managers en consultancywerk dan in de rest van Europa. Meer financiering van niet-academische bronnen zou juist kunnen duiden op meer praktijkgerichtheid. In Nederland is de belangrijkste bron van financiering echter wel de universiteit zelf. De bronnen van financiering wijzen er dus op dat de praktijk in Nederland een belangrijkere rol speelt dan in de rest van Europa. Kortom, het is duidelijk dat de bestuurskunde in Nederland zich minder ontwikkelt in de richting van de praktijk dan de bestuurskunde in andere landen. Aan de hand van de financiering en tijdsbesteding kan echter geen conclusie worden getrokken over de huidige praktijkgerichtheid van de bestuurskunde in Nederland in vergelijking met de rest van Europa.

Nederland kent een relatief lange traditie van bestuurskundigen (Kickert \& Stillman, 1999). Dit is wellicht een reden waarom de bestuurskunde als autonome discipline in Nederland belangrijker is dan in andere landen en waarom de academici minder een ontwikkeling ervaren en wensen in de richting van interdisciplinariteit. De resultaten uit deze studie sluiten voor Nederland dan ook aan bij de constatering van Wright (2011) en Rhodes (1991) dat de bestuurskunde niet zo interdisciplinair is als veelal wordt gesteld. De wetenschappelijke traditie in Nederland is wellicht ook een reden waarom de Nederlandse academici een minder sterke ontwikkeling ervaren en wensen in de richting van toegepast onderzoek dan de academici in andere Europese landen.

Concluderend kunnen we zeggen dat de bestuurskunde in Nederland in zoverre bestuurskundig dat er absoluut gesproken kan worden van de bestuurskunde, zeker in vergelijking met andere Europese landen. Wanneer bestuurskundig echter wordt gezien als de koppeling die de discipline maakt met het bestuur, blijkt dat de bestuurskunde een sterke wetenschappelijke insteek heeft en dat er slechts een beperkte ontwikkeling plaatsvindt naar meer aandacht voor het bestuur.

\section{Literatuur}

Bovens, M.A.P., Hart, P. 't, \& Twist, M.J.W. van. (2007). Openbaar bestuur: Beleid, organisatie en politiek. Alphen aan den Rijn: Kluwer.

Bueren, E. van. (2010). Bestuurskunde en bestuur: een verstoorde relatie? Bestuurskunde, 19(2), 82-85.

Bushouse, B.K., Jacobson, W.S., Lambright, K.T., Llorens, J.J., Morse, R.S., \& Poocharoen, O. (2011). Crossing the divide: Building bridges between public administration practitioners and scholars. Journal of Public Administration Research and Theory, 21: i99-i112. doi: 10.1093/jopart/muq063

Curry, D. (2014). Public administration as an academic discipline: Trends and changes in the COCOPS academic survey of European public administration scholars. Rotterdam: Erasmus Universiteit Rotterdam. 
Frissen, P., \& Twist, M. van. (2010). Bestuurskundige advisering als avontuur. In H. Aardema, W. Derksen, M. Herweijer \& P. de Jong (red.), Meerwaarde van de bestuurskunde: Liber Amicorum voor prof. dr. Arno F.A. Korsten (pp. 37-47). Den Haag: Boom Lemma uitgevers.

Gibsen, P.A., \& Deadrick, D. (2010). Public administration research and practice: Are academician and practitioner interests different? Public Administration Quarterly, 34(2), 145-168.

Groeneveld, S., Bouwman, R., \& Walle, S. Van de. (2014). Is er een trade-off tussen wetenschappelijke impact en praktijkrelevantie? Een analyse van de publicaties van bestuurs- en politieke wetenschappers in Nederland (2006-2011). Bestuurskunde, 24(1), 73-84. te verschijnen.

Hondeghem, A. (2013). Inleiding tot de bestuurskunde. In A. Hondeghem, W. van Dooren, F. de Rynck, B. Verschuere \& S. op de Beeck (red.), Handboek bestuurskunde: Organisatie en werking van het openbaar bestuur (pp. 21-49). Brugge: Vanden Broele.

Hughes, O.E. (1998). Public management and administration: An introduction. Houndsmills, Basingstoke: Macmillan.

Kickert, W., \& Stillman, R. (Eds.). (1999). The modern state and its study: New administrative sciences in a changing Europa and United States. Aldershot: Edward Elgar.

Korsten, A. (2006). Geschiedenis van de bestuurskunde. Verkregen via http://www. arnokorsten.nl/downloads.html

Moe, R.C., \& Gilmour, R.S. (1995). Rediscovering principles of public administration: The neglected foundation of public law. Public Administration Review, 55(2), 135-146.

Poelje, G.A. van. (1942). Algemene inleiding tot de bestuurskunde. Alphen aan den Rijn: Samson.

Pollitt, C. (2003). The essential public manager. Maidenhead: Open University Press.

Posner, P.L. (2009). The pracademic: An agenda for re-engaging practitioners and academics. Public Budgeting and Finance, 29(1), 12-26. doi: 10.1111/j. 1540-5850.2009.00921.x

Raadschelders, J.C.N. (2003). Government: A public administration perspective. Armonk, NY: M.E. Sharpe.

Randma-Liiv, T., \& Connaughton, B. (2005). Public administration as a field of study: divergence or convergence in the light of 'Europeanization'? Trames, 9(4), 348-360.

Rhodes, R.A.W. (1991). Theory and Methods in British Public Administration: The View from Political Science. Political Studies, 39(3), 533-554. doi: 10.1111/j. 1467-9248.1991.tb01627.x

Ringeling, A.B. (2007). Tussen distantie en betrokkenheid - Een bericht aan de tovenaarsleerlingen. Delft: Eburon.

Rutgers, M. (2001). Traditional Flavors? The different sentiments in European and American administrative thought. Administration and Society, 33(2), 220-244.

Talbot, C. (2005). Consilience and performance in 'the art of the state'. Public Policy and Administration, 20(1), 20-51.

Waldo, D. (1968). Scope of the theory of public administration. In J.C. Charlesworth (ed.), Theory and practice of public administration: Scope, objectives, and method (pp. 1-26). Philadelphia, PA: American Academy of Political and Social Science.

Wright, B.E. (2011). Public administration as an interdisciplinary field: Assessing its relationship with the fields of law, management, and political science. Public Administration Review, 71(1), 96-101. doi: 10.1111/j.1540-6210.2010.02310.x

Zalmanovitch, Y. (2014). Don't reinvent the wheel: The search for an identity for public administration. International Review of Administrative Sciences, 80(4), 808-826. doi: $10.1177 / 0020852314533456$ 